\title{
Landscape changes in Serra do Japi: legal protection or scientific expectation?
}

\author{
Cambios del paisaje en Serra do Japi: ¿protección legal o expectativa científica? \\ Elisa Hardt a*, Rozely Ferreira dos Santos ${ }^{\text {a,b }}$, Erico F Lopes Pereira-Silva ${ }^{\mathrm{c}}$ \\ *Correspondig author: a Campinas State University, Laboratory of Environmental Planning, \\ Campinas/São Paulo, Brazil, isahardt@yahoo.com.br \\ ${ }^{b}$ University of São Paulo, Department of Ecology, São Paulo, Brazil. \\ ‘Municipal Faculty “Professor Franco Montoro”, Mogi Guaçu/São Paulo, Brazil.
}

\begin{abstract}
SUMMARY
The creation of new legally protected areas brings many conflicts that distance the real landscape from the expected according to environmental law or conservation researchers. In this study, we mapped and compared the changes in Serra da Japi (São Paulo State, Brazil) throughout 40 years with scenarios of legal protection and scientific expectation on forest conservation, to evaluate the distance between them. This may allow us to infer the direction of historical changes and assist in the debate among decision makers. The results showed that most legal requirements on forest protection in the current landscape have been met. The 1960s was the period when the forest cover was closest to the desirable conservation stage. Although the Serra do Japi has maintained large areas of forests during the entire study period, human interference increased with the expansion of reforestation and urban areas, and access roads were identified as a primary potential driving forces of change. In addition, habitat loss was observed in the landscape, which can represent the first phase of a sequence of modifications detrimental to the environmental conservation of this protected area, including decision changes to land use. In conclusion, the changes evolved toward conservation expectations, but not toward the forest configuration of scientific expectation.
\end{abstract}

Key words: landscape ecology, environmental law, scenario, LUCC, Atlantic Forest.

\section{RESUMEN}

La creación de nuevas áreas legalmente protegidas trae muchos conflictos que alejan el paisaje real del que se espera por la legislación ambiental o por los investigadores en conservación. En este estudio se cartografiaron y compararon los cambios ocurridos en Serra do Japi (Estado de São Paulo, Brasil) a lo largo de 40 años con escenarios de protección legal y de expectativa científica sobre la conservación de bosques, buscando evaluar la distancia entre ellos. Este estudio nos permite inferir acerca de la dirección de cambios históricos y contribuye al debate entre tomadores de decisión. Los resultados mostraron que la mayoría de las exigencias legales de protección forestal fueron cumplidas en el paisaje. La década de 1960 fue el periodo con cobertura forestal más próxima a la deseada para la conservación. Aunque Serra do Japi ha mantenido grandes áreas de bosques en todo el periodo estudiado, la influencia humana se incrementó con la expansión de plantaciones forestales, de áreas urbanas y principalmente de las carreteras de acceso, identificadas como potenciales fuerzas conductoras de cambio. Además, se observó pérdida de hábitat en el paisaje que puede representar una primera fase de una secuencia de cambios perjudiciales para la conservación ambiental de esa área protegida. Esto incluye cambios en la decisión del uso del suelo. En conclusión, los cambios evolucionaron en dirección a las expectativas de la conservación, pero no hacia la configuración de bosques bajo una expectativa científica.

Palabras clave: ecología de paisaje, legislación ambiental, escenario, CUCS, bosque atlántico.

\section{INTRODUCTION}

In the last decades, Brazil has received much attention around the world due to the creation of new legally protected areas (Jenkins and Joppa 2009), preserving singular ecosystems threatened by the advance of human activities. However, this initiative also brought many conflicts with the population, mainly regarding different interests on land use (Abakerli 2001), such as the conflict between state government and residents in the creation of protected areas of restrictive uses that prohibits the territorial occupation (Payés et al. 2013), principally in regions of urban expansion. During this time, these conflicts created pressures that have changed the protected landscapes, distancing the real landscape from the expected legal scenario. The understanding of the distance between these scenarios may aid in the interpretation of the consequences of the consensus of social negotiations. In addition, the scenarios of public consensus in the Brazilian territory, supported or not by legal documents, are usually distant from those aimed by most conservation researchers (Terra and Santos 2011), but few studies have examined this issue. Knowing how close or far a landscape is from the legal requirements or the ideal condition requires studies that examine the 
expected scenarios in face of land use changes observed throughout time. This is considered by many authors a good way to obtain information on conservation policies (Frapolli 2007, Petrosillo et al. 2009). In this context, the present study evaluates the changes in land use in the last 40 years of a protected Atlantic Forest, hierarchizing the distances in relation to two scenarios of conservation: enforcement of the legal protection and technically ideal scenarios. This strategy may allow us to infer if the historical changes evolved toward expectations of conservation, legal requirements or interests on land use.

\section{METHODS}

The study area comprised 14,060 ha of the "Serra do Japi”, a mountainous region in Jundiaì, southeastern Sao Paulo State, Brazil. This area encompasses 8,000 ha of conserved Atlantic Forest, of which 2,000 ha are protected as a Biological Reserve (SJBR). In spite of the increasing urban pressure, this region is protected at all administrative levels: municipal, state, and federal.

The last 40 years of changes in the study area were evaluated using three land use maps based on aerial orthophotos from 1962, 1994 and 2005, scale of 1:25,000, in ArcGis $^{\circledR}$.

We designed two important scenarios of expectations to the forest conservation of Serra do Japi from different criteria for the maintenance of native forests. The first scenario represents the set of legal acts of forest protection (legal scenario) and the second scenario was a scientific technically ideal proposal for the forest conservation (ideal scenario). The legal scenario was represented in a map that illustrates all areas that according to forest laws must be forests (table 1). In areas without legal protection, the land uses recorded in 2005 were maintained. The ideal scenario proposed the maintenance of natural forests in different forms of relief, with special attention to local connectivity and its role in the regional landscape (table 2).

Table1. Protection measures for the forest cover of Serra do Japi and its corresponding legal acts.

Medidas de protección para la cobertura forestal de Serra do Japi y sus correspondientes acciones legales.

Legal act Mapped forests and materials used

Forest code. Law 4.771/65 - CONAMA 302 Areas of Permanent Preservation (APP):

and 303/02

Forests around streams, springs, lakes, dams and wetlands: land use map of $2005+$ urban boundary + drainage ${ }^{\circledR}$ function "buffer wizard” of ArcGis;

Upper-third of hillsides; and slope greater than $45^{\circ}$ : MDT ${ }^{\circledR}$ function "Slope” of ArcGis ${ }^{\circledR}$ slope map.

Forest as a natural asset

CONDEPHAAT 11/83

Area of environmental protection (AEP).

Laws 4.023 and 4.095/84

Protection of the Atlantic Forest. Decree 750/93 and Law 11.428/06

Creation of the biological reserve.

Law 3.672/91 and Law SNUC 9.985/00
Forests found in 1983 within the boundaries of the heritage protected area: land use map of 1994 (nearest year).

Forests protected by the Forest Code; existing forests in 1984 within the boundaries of AEP: map of 1994.

Atlantic Forest in advanced and intermediary stages of regeneration in 1993: map of 1994.

Existing forests within the boundaries of the protected area SJBR, and its categorization in advanced stages of regeneration: map of 1994.

Table 2. Criteria of the construction of the ideal scenario for Serra do Japi. Criterios para la construcción del escenario ideal para Serra do Japi.

\begin{tabular}{ll}
\hline \multicolumn{1}{c}{ Objectives } & \multicolumn{1}{c}{ Criteria of forest conservation } \\
\hline Moratorium & $\begin{array}{l}\text { Maintain the existing fragments in intermediary and advanced stages of } \\
\text { regeneration. }\end{array}$ \\
\hline Biodiversity conservation & $\begin{array}{l}\text { Maintain or recover forests in a range of relief gradient: fluvial lowlands, } \\
\text { convex hills, mountains, and hilltops. }\end{array}$ \\
\hline $\begin{array}{l}\text { Protection of water resources and erosion prevention, } \\
\text { mudslides and soil loss }\end{array}$ & $\begin{array}{l}\text { Maintain forests along springs, lakes, dams, high slope areas, top of hills } \\
\text { and mountains, according to the Forest Code. }\end{array}$ \\
\hline Protection of potentially floodable areas & Maintain or recover fluvial lowland forests. \\
\hline Improvement of local connectivity & $\begin{array}{l}\text { Broaden the strip of gallery forest of } 30 \text { m, required by the Forest Code, to } \\
70 \mathrm{~m}, \text { based on a study on border effect for the area (Hardt 2010). }\end{array}$ \\
\hline
\end{tabular}




\section{RESULTS}

The historical mapping and the interpretation of the legal protection measures for the area allowed the characterization and spatial configuration of the land use and co- ver of the Serra do Japi throughout the years and its legal expectation (figures 1 and 2).

In the construction of the legal scenario, we created maps of forest cover for each one of the legal protection measures (figure 3A-E), which mostly overlapped each

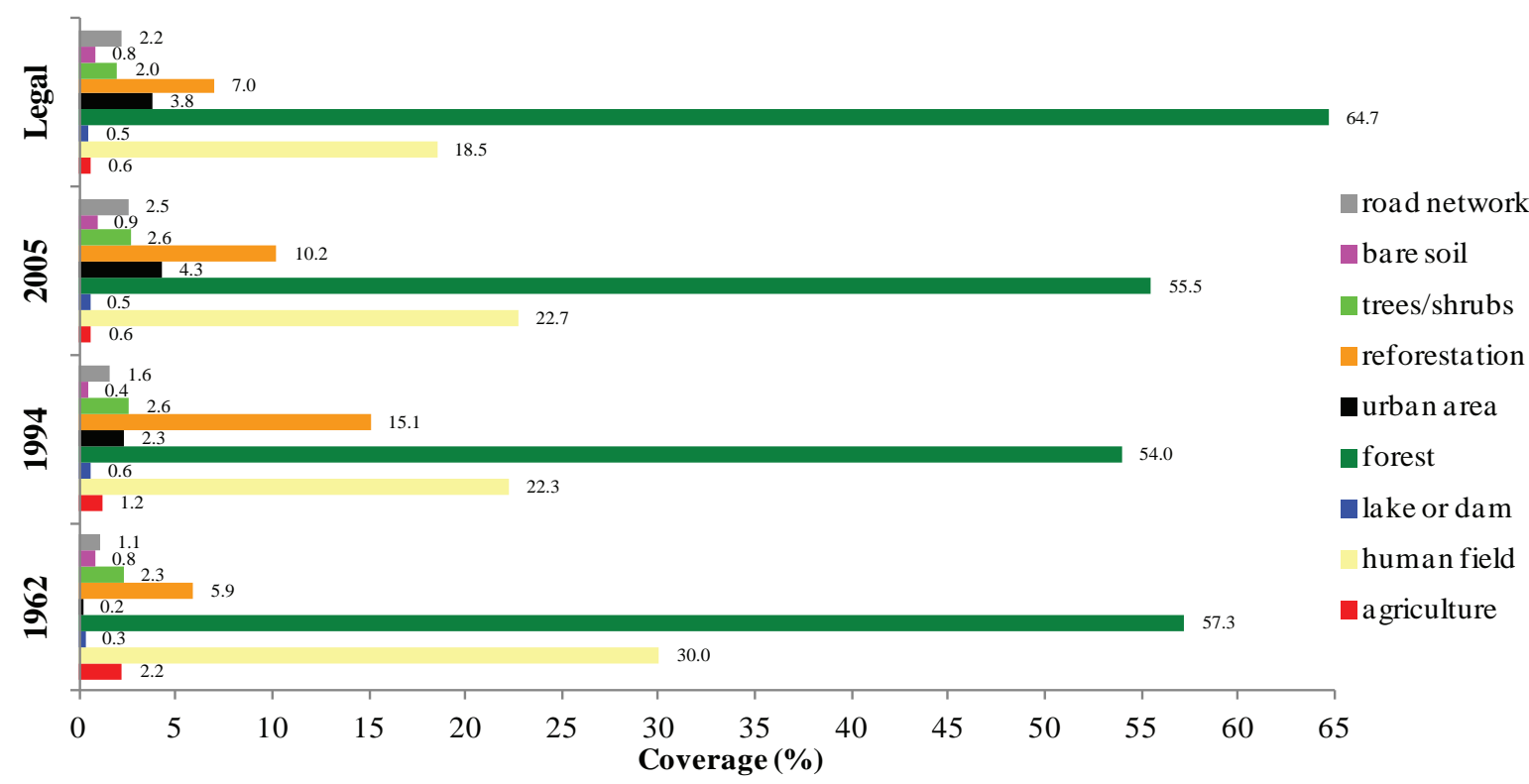

Figure 1. Characterization of the land use and cover of the Serra do Japi (Jundiaí/Brazil) in 1962, 1994, 2005 and legal scenario. Caracterización del uso y cobertura de la tierra de Serra do Japi (Jundiaí/Brazil) en 1962, 1994, 2005 y escenario legal.
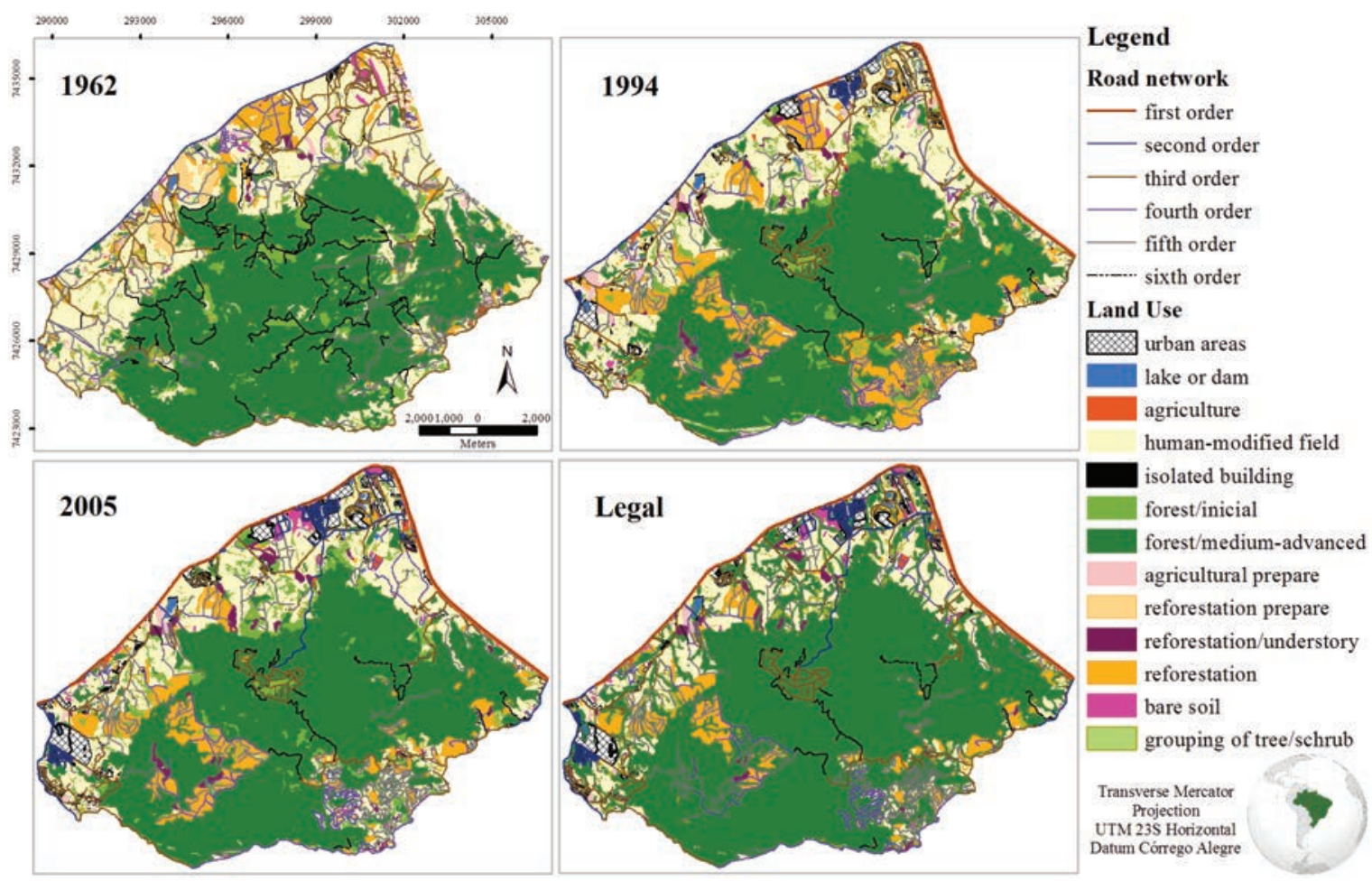

Figure 2. Land use map of Serra do Japi (Jundiaí/Brazil) in 1962, 1994, 2005 and legal scenario. Mapa del uso de la tierra en Serra do Japi (Jundiaí/Brazil) en 1962, 1994, 2005 y escenario legal. 


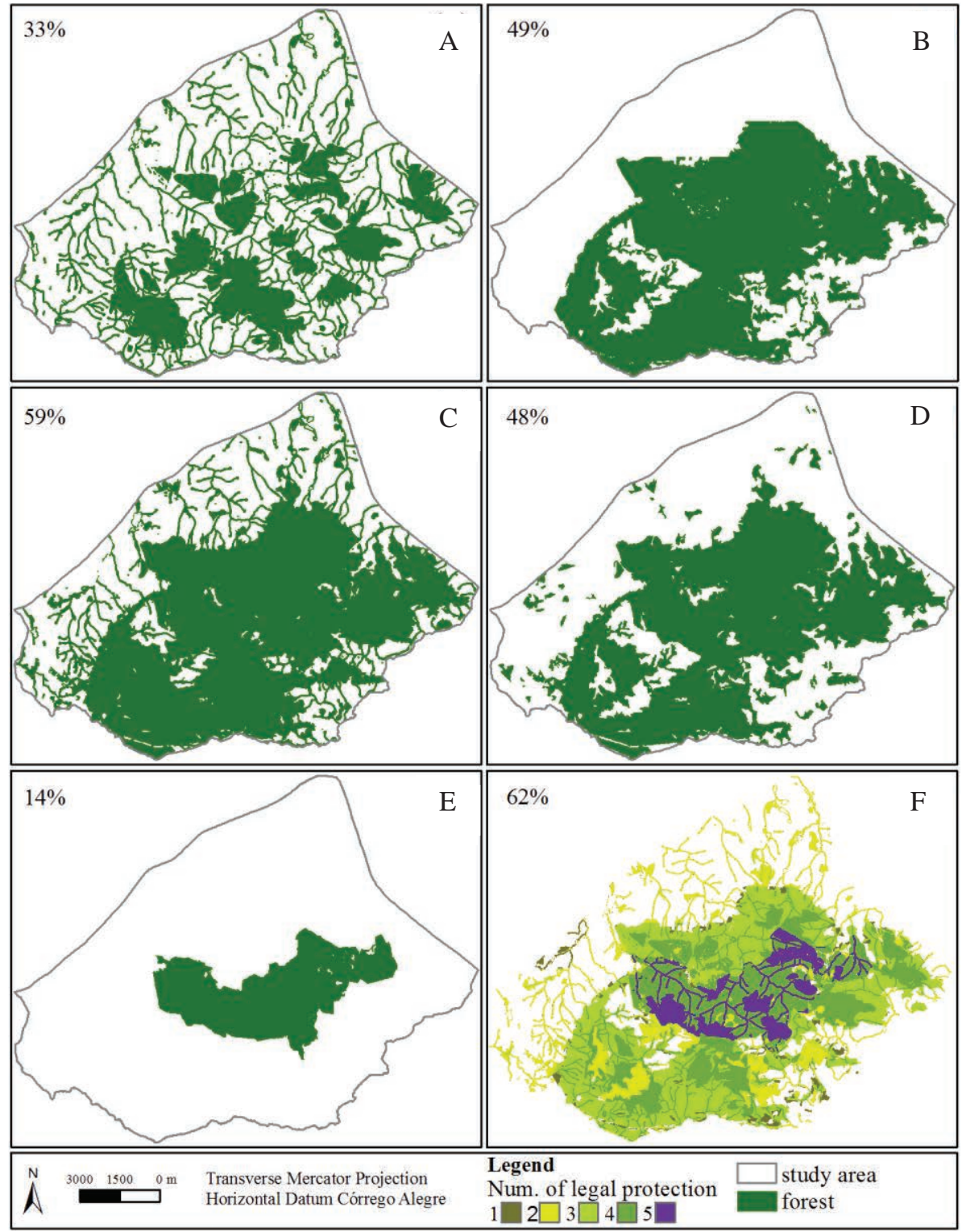

Figure 3. Forest cover (\%) of Serra do Japi legally protected: (A) Forest Code-APP, (B) protected heritage, (C) environmental protection-AEP,(D) Atlantic Forest, (E) protected area and (F) total legal protection.

Cobertura de bosque (\%) del área legalmente protegida en Sierra do Japi (A) Código Forestal, (B) patrimonio protegido, (C) protección ambiental-AEP, (D) bosque Atlántico, (E) área protegida y (F) protección legal total.

other (figure 3F). For the ideal scenario, we also created maps of forest cover with the spatial configuration of each one of the technical-scientific conservation criteria (figure 4A-C), with a final proposal for the ideal forest cover of Serra do Japi (figure 4D).

\section{DISCUSSION}

The legal measures seek to protect $62 \%$ of the Serra do Japi as forest, while from a technical-academic view the ideal conservation scenario aims to protect $83 \%$ of the forest cover in advanced-intermediary stages (figures 3 and 4). In the ideal scenario, a large forest portion should be concentrated in mountainous areas and land use should be restricted to the historically urban territory. Even the areas of human interference would be connected to the forest core by corridors of gallery forests and small fragments (figure 4). Under the premise of conservation, what would be the distance between these scenarios and the landscape observed in recent years?

Based on the legal requirements of forest protection, the current landscape fulfills $90 \%$ of the expected. This percentage could be even higher if the legal protection of the gallery forests and hills (forest code) was more effective $(71 \%)$. On the other hand, the comparison of the scientific expectation scenario with land-use and land-cover 


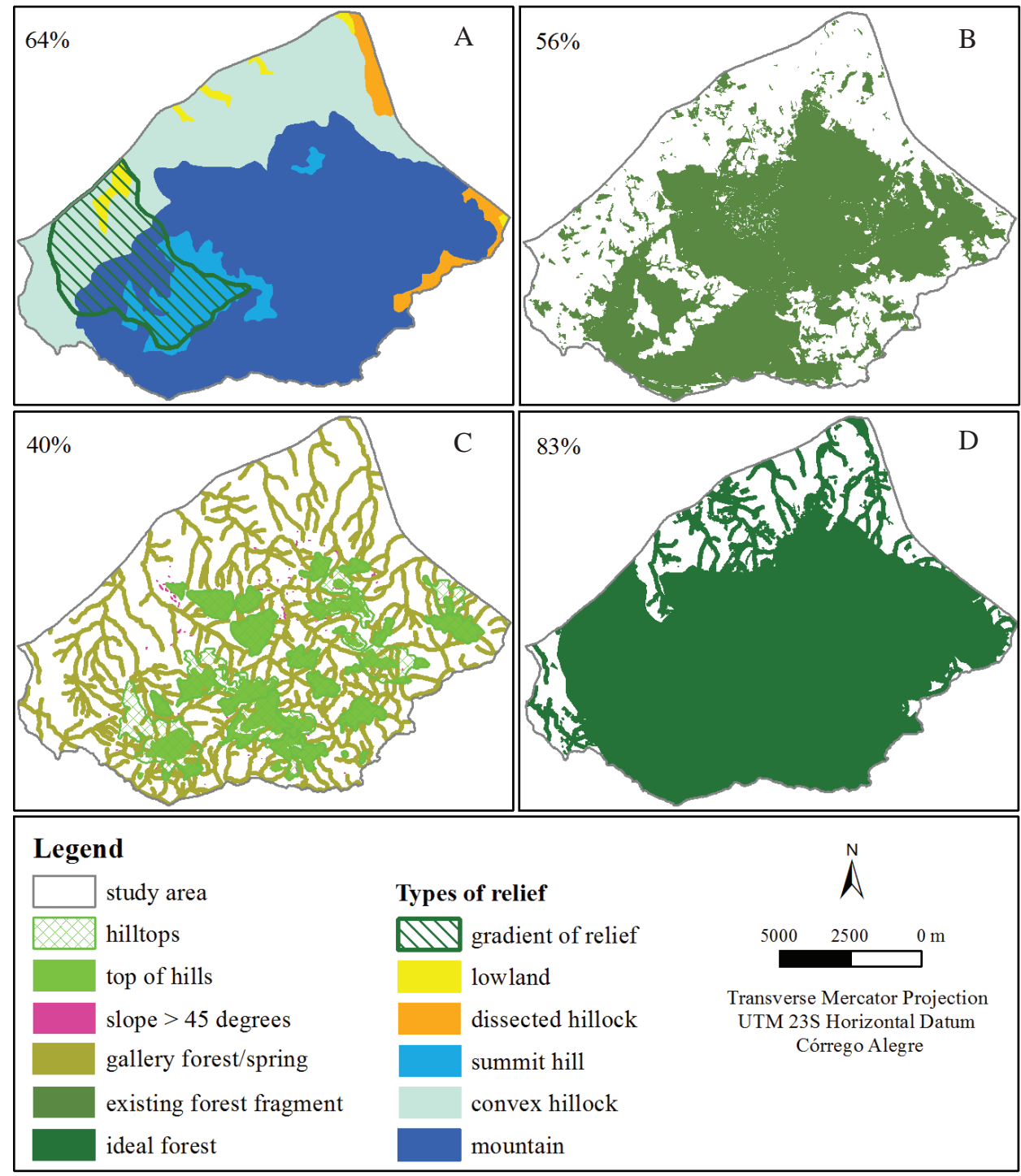

Figure 4. Criteria used in the construction of the ideal conservation scenario of the Japi forest cover (\%): (A) relief types, (B) current forests, (C) expansion of Forest Code-APP and (D) ideal forest cover.

Criterios utilizados en la construcción del escenario ideal para la conservación de la cobertura forestal (\%) de Japi: (A) tipos de relieve, (B) bosques actuales, (C) expansión del Código Forestal-APP y (D) cobertura forestal ideal.

change (LUCC) revealed that they were very distant from this proposal. In terms of forest area, 1962 was the period closest to the expected, with $31 \%$ less from the desired. The legal and scientific expectation scenarios have distinct configurations, probably because the environmental laws are not focused only on biodiversity conservation.

Despite these differences, the historical predominance of the percentage of forests over other types of land use demonstrates the local concern with the conservation of Serra do Japi. Since the 1960s, Serra do Japi had more than $60 \%$ of its area composed of trees, such as reforestation areas, tree clusters, and mainly forests (figure 1). In addition, the successional evaluation of the forest suggests that human interference did not prevent the evolution of the natural development process. In thirty years
(1962-1994), $60 \%$ of the forest in early secondary stages became intermediary and advanced and in the following ten years (1994-2005), additional $32 \%$ evolved to advanced stages.

Contrary to this conservation history, especially between 1962 and 1994, urban areas, artificial dams and reforestation areas expanded (figure 1). Despite changes in exploitation trends between 1994 and 2005, with reduction in the investments in new areas of reforestation in regions that should be legally covered by forests (figure 2C-D). The most expressive and concerning change was the widening of access roads, not in extension but in area (figure 1). This expansion was a consequence of the widening of old trails of 1962 and new connecting roads between neighboring municipalities, access to new human settlements 
and economic activities, such as the complex road system of reforestation areas, responsible for the fragmentation of forests that should be protected (figure 2). Although in the decades following 1960 the road circuitry decreased (Dramstad et al. 1996), widening roads had new connective roles that increased their potential of interference on forests. Along with urbanization, the increase in access is a driving force of high potential of change (Antrop 2005) and should not be the reality of a protected area. In addition, although the forest cover was always over $50 \%$, with some additions by dilation due to the natural regeneration or recovery of gallery forests, some habitat losses occurred. These losses occurred in different patterns of change: by perforation (mainly 1962), dissection (land developments in 1994), fragmentation (mainly 1994), and shrinkage (south and southwest areas). Are alarming losses resulting from economic activities, such as the selective exploitation of timber in 1962, silviculture in 1994, and urban clusters in 2005. There is a probable sequence of habitats changes under human influence that starts with patches of land use perforating the matrix, undergoes fragmentation, and can cause the extinction of habitats due to the attrition effect (Formam 1995, Dramstad et al. 1996, Farina 2008). It should be pointed out that a growing human interference usually alters the management decisions based on the changes in people's perception about the landscape (Antrop 2005). Therefore, we believe that the view of social groups may be changing, increasing the risks on protected areas or on those of great importance for forest conservation.

The results allowed us understanding that exist a distance between the scenarios of legal and ideal and showed that historical changes have been more engaged with the expectations of conservation than with the interests on land use. This strategy of analysis may be useful in the evaluation of conservation policies regarding their effectiveness, consequence and distance from the academic opinion.

\section{CONCLUSIONS}

The changes occurred in Serra do Japi evolved toward the expectation of conservation, but not toward the configuration of forests expected by the environmental legal protection or the scientific expectation. The historical evaluation of the changes in land use alerts for the expansion of urbanization and mainly the increase in accessibility, as important driving forces of change in the Japi landscape.

\section{ACKNOWLEDGMENTS}

The authors acknowledge the support received from FAPESP (São Paulo State Foundation for Science Funding) through concession the $\mathrm{PhD}$ scholarship (process number 06/55385-0) and the financial support (process number 08/01505-0).

\section{REFERENCES}

Abakerli S. 2001. A critique of development and conservation policies in environmental sensitive regions in Brazil. Geoforum 32: 551-565.

Antrop M. 2005. Why landscapes in the past are important for the future. Landscape and Urban Planning 70: 21-34.

Dramstad W, J Olson, R Forman. 1996. Landscape ecology principles in landscape architecture and land-use planning. Washington D.C. USA. Island Press. Harvard University Graduate School of Design, American Society of Landscape Architects and Island Press. 80 p.

Farina A. 2008. The landscape as a semiotic interface between organisms and resources. Biosemiotics 1(1): 75-83.

Formam R. 1995. Land mosaics: the ecology of landscapes and regions. Cambridge, UK. Cambridge University Press. $605 \mathrm{p}$.

Frapolli E, B Orozco, M Moheno, C Manrique, G Fernández. 2007. Biodiversity conservation, traditional agriculture and ecotourism: Land cover/land use change projections for a natural protected area in the northeastern Yucatan Peninsula, Mexico. Landscape and Urban Planning 83: 137-153.

Hardt E. 2010. Conservação ambiental em cenários de uso: medidas de mudanças, heterogeneidade e valoração da paisagem. Tese de doutorado. Campinas, Brasil. Faculdade de Engenharia Civil, Arquitetura e Urbanismo, Universidade Estadual de Campinas. 192 p.

Jenkins C, L Joppa. 2009. Expansion of the global terrestrial protected area system. Biological Conservation 142: 21662174.

Payés A, T Pavão, R Santos. 2013. The conservation success over time: Evaluating the land use and cover change in a protected area under a long re-categorization process. Land Use Policy 30: 177-185.

Petrosillo I, N Zaccarelli, T Semeraro, G Zurlini. 2009. The effectiveness of different conservation policies on the security of natural capital. Landscape and Urban Planning 89: 49-56.

Terra T, R Santos. 2011. Juréia: um bom (ou mau?) exemplo da influência de políticas sobre a conservação da natureza e a qualidade de vida. Revista de Estudos Universitários 37: 37-49. 